\title{
Unions and Nonunion Pay in the United States, 1977-2015
}

\author{
Patrick Denice, ${ }^{a}$ Jake Rosenfeld ${ }^{\mathrm{b}}$
}

a) The University of Western Ontario; b) Washington University in St. Louis

Abstract: We provide the most extensive investigation into the connection between union power and nonunion worker pay to date. Leveraging nearly four decades of Current Population Survey (CPS) data on millions of U.S. workers, we test whether private sector union density, measured at the occupation and occupation region levels, helps raise average wages among unorganized private sector workers. We find stable and substantively large positive effects of private sector union strength on nonunion private sector workers' wages, especially for men. These results are robust to the inclusion of controls for the risk of automation, offshoring, the related rising demand for skill, overall employment levels, industry, and the strength of public sector unions. Disaggregating the results by occupation reveals positive and substantively large union spillover effects across a range of occupations, including those not transformed by automation, offshoring, or rising skill demands. These disaggregated results also indicate that occupational segregation limits the positive spillover effects from unions to nonunion women workers: in highly organized occupations, nonunion women benefit, but there are comparatively few women in these segments of the labor market.

Keywords: unionization; nonunion labor; wages; labor markets

Citation: Denice, Patrick, and Jake Rosenfeld. 2018. “Unions and Nonunion Pay in the United States, 1977-2015." Sociological Science 5: 541-561.

Received: June 12, 2018

Accepted: July 10, 2018

Published: August 15, 2018

Editor(s): Jesper Sørensen, Kim Weeden

DOI: $10.15195 /$ v5.a23

Copyright: (C) 2018 The Author(s). This open-access article has been published under a Creative Commons Attribution License, which allows unrestricted use, distribution and reproduction, in any form, as long as the original author and source have been credited. @()
VERAGE earnings for millions of American workers have been frozen for four decades. The issue has grabbed the attention of leading policymakers, journalists, and academics, generating numerous theories about the underlying source of this stubborn trend. ${ }^{1}$ Prominent explanations include automation, the offshoring of core production jobs, the related rising demand for skilled workers, and the dramatic decline in the power of the U.S. labor movement. In recent years, the institutionalist account that situates weakened labor unions at the center of wage stagnation has gained popularity. Research from this perspective contends that union decline is a core determinant of wage trends for many workers, not only through the wage losses experienced by formerly organized workers but also through the positive "spillover" effects strong unions once provided to unorganized workers (Rosenfeld, Denice, and Laird 2016; Western and Rosenfeld 2011). A related line of research highlights how union decline has led to rising executive pay (Jaumotte and Buitron 2015; Shin 2014). What these studies share is a focus on the changing ways in which organized labor influences nonunion workers' economic fortunes. After all, even at the U.S. labor movement's peak, most workers were nonunion. For unions to compete alongside the other major determinants of flattened wages and rising inequality, they must be connected to the economic fate of nonmembers, at least in times when and places where labor was strong.

In this article we provide the most extensive investigation into the connection between union power and nonunion worker pay to date. We leverage nearly four decades of data on millions of U.S. workers to test whether union density, 
measured at various levels, helps raise average wages among unorganized workers. We focus on union effects on private sector, nonunion workers, the group that encompasses the majority of the current workforce. This is also the group that was most exposed to rapid shifts in late-twentieth- and early-twenty-first-century capitalism. Figure 1 below plots the change in median weekly wages from 1977 to 2015 for this population. We limit the samples to nonunion, full-time, private sector workers. We exclude senior managers and executives from the figure and from all subsequent analyses, as our focus is on the experiences of average American workers. We also exclude the self-employed, as by definition, they cannot belong to a labor union.

As displayed, the general trend of wage stagnation masks important differences by subgroup. Steadily rising pay for women has helped offset stagnant wages for men. Pay for nonunion women has risen 18 percent between 1977 and 2015, buoyed by (limited) occupational desegregation (Mandel 2013) and increases in labor force attachment (Hollister and Smith 2014; Percheski 2008). For unorganized male workers in the private sector, it has increased by just 1.7 percent. Over this time period, the private sector unionization rate collapsed from 22 percent to 7 percent (Hirsch, Macpherson, and Vroman 2001). The question we are interested in is whether these patterns of nonunion wages for men and women are related to the declining fortunes of unions in the private sector.

This question has been asked before (for similar approaches, see Rosenfeld et al. 2016; Western and Rosenfeld 2011). Our article expands on this and other related work in key ways. First, we test whether the union influence remains after adjusting for prominent counterexplanations for the decades-long stagnation in many Americans' pay, namely automation, globalization, and the growing demand for skilled labor. Past treatments all suffer from possible endogeneity, as they fail to disentangle unions' direct influence on nonunion pay from other contributors to wages that are also implicated in labor union decline. For example, organized labor's concentration in the capital-intensive manufacturing sector meant that unions were especially vulnerable to the acceleration of offshoring and automating that shuttered factories and shed workers across the United States. Thus, what may appear to be the effects of union decline on nonunion pay in earlier studies may actually stem from U.S. employers' turn toward overseas labor and the automation of many domestic positions.

Second, we move beyond the approach of measuring union strength at the industry level to an examination of how union strength relates to nonunion wages within occupations. An occupational-level analysis offers a number of advantages over prior treatments. For one, it aligns research on organized labor and inequality with the longstanding focus in sociology on the primacy of occupations in structuring pay and, as a result, influencing inequality trends (Mouw and Kalleberg 2010; Weeden 2002). It also provides another way to disentangle union effects on wages from other dominant explanations for wage stagnation and rising inequality. By disaggregating the union effect by occupation, we can see whether any relationship exists between union density and nonunion wages outside of those occupations that are most prone to labor-saving technological change and offshoring. 

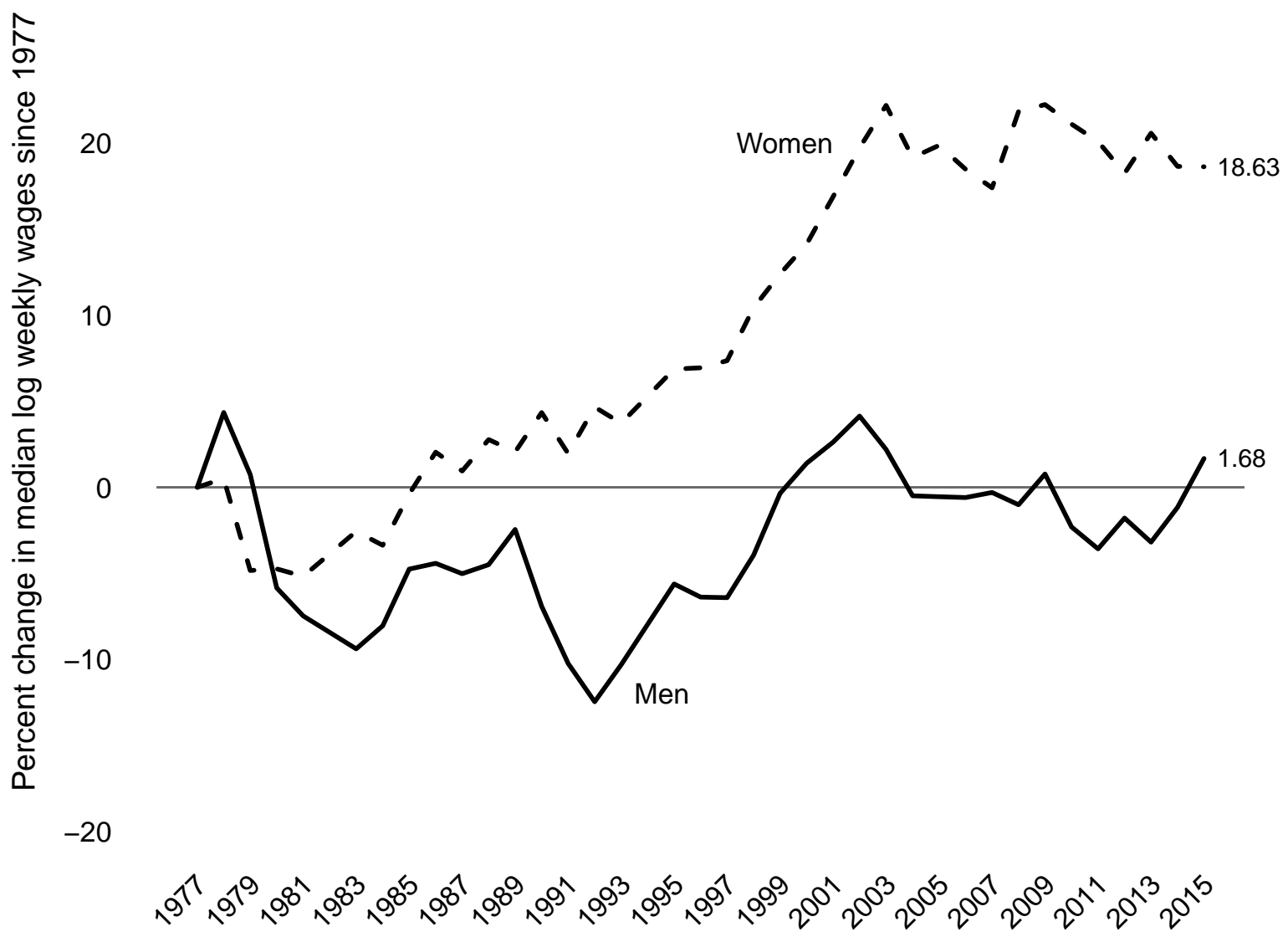

Figure 1: Trends in nonunion median weekly wages, 1977-2015.

Further, an occupational-level analysis helps us solve a puzzle from past treatments on the topic. Prior research finds substantially larger union spillover effects for men than women (Rosenfeld et al. 2016; Western and Rosenfeld 2011). But the theorized channels through which unions should boost nonunion pay are not gender specific. We argue that the curious results from prior research likely stem from occupational segregation. A focus on union spillover effects within occupations over time allows us to test this hypothesis.

Third, unlike prior work on the topic, we include measures of public sector union strength in our investigation. Public sector unions emerged later than private sector ones and emerged precisely in areas where private sector unions were already powerful (Goldfield and Bromsen 2013; Kochan 1973). This correlation implies that prior findings focusing only on the effects of private sector union strength on nonunion pay may be picking up the influence of public sector unions, especially in recent years, when public sector unions have remained comparatively strong. Researchers tend to emphasize how intraoccupational public-private compensation comparisons are difficult given the unique nature - and therefore lack of comparability—of 
certain public sector occupations, especially the protective services (Lewin, Keefe, and Kochan 2012:773). But this ignores large occupations-teachers, nurses, administrative assistants, building cleaners, and so on-that have both private and public sector corollaries. Moreover, many of the most politically active unions have predominantly public sector memberships. Should spillover effects occur through political channels, as has been theorized (Ahlquist 2017; Western and Rosenfeld 2011), then failing to control for public sector union strength may lead to inflated estimates of private sector unions' effects on the pay of nonmembers.

To foreshadow our results, we find stable and substantively large positive effects of private sector union strength measured at the occupation and occupation region levels on nonunion private sector workers' wages. These results are robust to the inclusion of controls for the risk of automation, offshoring, overall employment levels, and the strength of public sector unions. Although the overall spillover effect is larger for men than women, we find substantively large spillover effects for women within those occupations and regions where unions were once strong. Findings from past research suggesting that unions are primarily beneficial to nonunion men stem from the failure to examine occupational differences in union spillovers. Models indicate that unions are especially important to the wages of nonunion workers in occupations such as transportation, construction, and production work, where our counterfactual estimates indicate that weekly wages would be between $\$ 18$ (for women production workers in the East South Central region) and $\$ 180$ (for male construction workers in the Pacific region) higher if private sector unions remained as strong today as they were in 1977.

\section{Unions and Nonunion Wages within Occupations}

Traditionally, scholars have tested whether a union presence poses an economic threat to nonunion competitors (Farber 2005; Leicht 1989; Podgursky 1986). A strong union presence can threaten the economic well-being of a nonunion establishment in two primary ways. First, it may spark a unionization effort at the employer's plant. To ward off such a possibility, nonunion employers may raise their pay and benefits packages to match union levels. As one large nonunion employer recounted in the late 1970s, "Because we are such a union target, we find that we have to get our start rate at or almost at the union rate" (Foulkes 1980:154). This strategy was once common, with industry leaders such as Eastman Kodak monitoring and matching union pay scales closely in order to placate its nonunion workforce (Jacoby 1997). Second, a strong union presence may attract nonunion workers to the higher pay that often accompanies a union job. Here, too, the solution for the nonunion employer is to narrow pay differentials between the union and nonunion workers, lessening the prospects of losing talented workers to an organized establishment.

If these two types of threat effects operate within broad industries, as prior research has demonstrated (Rosenfeld et al. 2016; Western and Rosenfeld 2011), then they should, if anything, be stronger within occupations. Industry groupings combine workers of varying occupations from management on down. An employer concerned about losing employees to a neighboring, organized establishment offering higher pay is likely to raise wages among similar types of workers. Although 
employers must of be mindful of equity concerns that arise from adjusting pay for one set of workers, the direct beneficiaries of any adjustment will be those in the occupation receiving higher pay in the unionized establishment. And, absent an employer simply agreeing to a union (in recent years, a rare occurrence), the typical route to a successful organizing drive in the private sector involves petitioning the National Labor Relations Board (NLRB). As part of the petition, the union must decide on an appropriate "bargaining unit," defined by the NLRB as a "group of two or more employees who share a community of interest and may reasonably be grouped together for purposes of collective bargaining" (National Labor Relations Board 1997:12). Although there is latitude in terms of defining which employees share "a community of interest," the general result of the guidelines is to create bargaining units based on occupations within establishments. As a result, the threat of an organizing drive that stems from a strong union presence at neighboring establishments should be felt particularly by employers of workers within the same (or similar) occupation as their unionized neighbors.

More recently, scholars have suggested that the potential influence of unions on nonunion pay extends beyond economic threat. Western and Rosenfeld's (2011:5159) broader categorization includes cultural, institutional, and political channels. Culturally, the broad "norms of economic fairness" (Ahlquist 2017:517-9) unions establish should benefit nonunion workers within industries (as previously tested) and occupations. The institutional channel also helps boost wages within occupations. In 2015, New York State's Fast Food Wage Board, which included a secretary-treasurer of the Service Employees International Union (SEIU), recommended increasing fast-food employees' pay to $\$ 15$ per hour, significantly raising compensation levels for the food service occupation within the fast-food industry. ${ }^{2}$ Politically, unions' push for higher minimum wages, to take one prominent example, raises the pay of bottom-rung occupations within industries.

These various pathways through which unions boost nonunion pay are largely unobserved mechanisms in the available large-scale data sets, such as the Current Population Survey (CPS), that we rely on. We observe union power, proxied by membership rates at various levels, alongside workers' wages and a range of other core determinants of pay. What is most important for our purposes is not which mechanism is most impactful but rather that the pathways theorized operate within occupations and not just industries. This is especially important given sociologists' emphasis on the importance of occupations in structuring wage outcomes and inequality trends. Weeden, for example, argues that unionization is a core strategy through which incumbents erect boundaries around occupations, helping to raise occupational rewards (2002). Thus, we depart from past research and situate our analysis at the occupation and occupation region levels. Whereas recent studies at the industry level find that the impact of unions on nonunion private sector pay is larger for men than women (Rosenfeld et al. 2016; Western and Rosenfeld 2011), we hypothesize that this is largely due to occupational segregation: Within industries in the private sector, men historically have been concentrated in more highly unionized occupations. Focusing on changes in nonunion pay within occupations, by contrast, should result in similar union effects for unorganized men and women in the private sector. 


\section{Data and Methods}

We rely on various series of the CPS as the primary data source used in our analyses. The CPS is a monthly survey conducted by the Bureau of Labor Statistics of between 50,000 and 60,000 households and is commonly used to investigate wage trends and the role of unions given its rich set of economic and demographic variables and large samples. The CPS began asking respondents about union membership in its May 1973 survey. In 1983, it included its union question in the larger Outgoing Rotation Group (ORG) files. For 1977 through 1981, we use the May files, and for 1983 through 2015, we use the ORG files (we exclude 1982 data as no union question was asked in that year). Our series starts in 1977 because the CPS altered the wording of the union question beginning in 1977, rendering comparisons with earlier years problematic (Hirsch and Macpherson 2003:351).

Following recent research on related topics, we limit our samples to full-time (those working 30+ hours per week), nonunion employees in the private sector with positive earnings who are not self-employed or senior managers or executives (Rosenfeld et al. 2016). We exclude outlier earners from our samples by dropping respondents reporting hourly earnings less than $\$ 1$ per hour or more than $\$ 100$ per hour in 1979 dollars (Lemieux 2006). We exclude allocated earners from our data because the CPS does not include union status or sector in its allocation model (Brueckner and Neumark 2014:210). To identify allocated earners across the 1977-2015 series, we follow the procedure outlined by Hirsch and Schumacher (2004:Table 2). We exclude data from 1994 and from three-quarters of 1995 given the lack of valid allocation flags in those surveys.

Constructing a real weekly wage series from 1977 to 2015 requires adjusting for inflation and top-coded values. We convert weekly wages to 2015 dollars using a hybrid deflator. We use the Consumer Price Index experimental series (CPI-UX1) for 1977 to 1978 and the Consumer Price Index research series using current methods (CPI-U-RS) for 1979 to 2015 (for a similar approach, see Baker 2007). For the results presented in the tables, we follow Lemieux (2006) and multiply the weekly wages of respondents with top-coded earnings by 1.4. In supplemental analyses, we experimented with two other strategies: First, we multiplied top-coded values by the Pareto estimates of mean earnings above the top code provided by Hirsch and MacPherson (2017). Second, we modeled median weekly wages, thus avoiding the need to adjust top-coded values. Both supplemental analyses produced results similar to those shown and are available upon request.

Our empirical investigation is comprised of multilevel analyses in which we model the relationship between occupation region private sector unionization rates and $\log$ weekly wages for nonunion private sector workers. These models control for a set of individual and occupation region covariates (for a full listing and description of all variables and values, please see the Data Appendix of the online supplement). We generate a 25-category occupation measure based on a timeconsistent system developed by Autor and Dorn (2013) and Dorn (2009). Dropping executives and senior managers from the scheme results in 24 occupations across 9 CPS regions, or 216 occupation regions in all. 
The occupation region private sector unionization rate is our key independent variable. A set of occupation region controls helps us adjust for the impacts of other dominant explanations for wage stagnation in the modern economy. We include an index measuring the average routine task content of each occupation to control for that occupation's risk of automation (Autor and Dorn 2013). This index increases from 0 to 10 in the prevalence of routine tasks in each occupation. ${ }^{3}$ To control for the growing demand for high-skill workers, we include a variable capturing the percentage of workers in each occupation region with a bachelor's degree or more. To control for the manufacturing decline associated with the expansion of global trade, we include a measure of the percentage of workers in manufacturing industries for each occupation region. Although this measure is correlated with our occupations, it is not synonymous. For example, a respondent who works as a security guard would be in the protective services occupation (code 17; see the Data Appendix of the online supplement for a complete listing of occupational codes), whereas the percentage of manufacturing workers in his or her occupation region would capture the fraction of security guards in a given region employed by manufacturing firms. Finally, to differentiate the (potential) impact of private sector from public sector union strength, we control for each occupation region's public sector organization rate.

Our individual-level covariates, drawn from the CPS files, include education (4-category measure), potential experience and its square, ${ }^{4}$ race and/or ethnicity (5-category variable), industry (8-category variable), metropolitan status (3-category variable), region, and hours worked per week. We present core individual- and occupation region-level descriptives in Table 1.

We estimate standard log-linear models of weekly wages separately for men and women. Model 1 of Tables 2 and 3, our baseline model, includes our core controls. Model 2 adds occupation fixed effects, constraining the variation to be within occupation, over time. Model 3 adds occupation region fixed effects, constraining the variation to be within occupation region, over time. In all models, we cluster standard errors by occupation region.

Generating predictions in the original scale (i.e., dollars) from standard loglinear models requires retransforming the predicted means from the log back to the level form. This retransformation introduces bias, as exponentiating the mean of the $\log$ does not necessarily produce an accurate prediction of the mean in the original scale (Duan 1983). Further, there is no consensus regarding what correction (or "smearing") factor is preferable for addressing this bias (Rosenfeld et al. 2016:31). Instead, to generate predicted values in level form, we reestimate generalized linear model (GLM) versions of the models from Tables 2 and 3, specifying a log-link and gamma distribution family (Kleykamp 2013; Rosenfeld et al. 2016 employ a similar strategy). This approach does not require a transformation of the dependent variable in the first place. Based on these GLM models, we predict wages for nonunion workers under various scenarios and present them. We provide a full set of results from these models in Tables A1 and A2 of the Data Appendix of the online supplement; significance levels and signs for the coefficients of key covariates are similar to the log-linear estimates. 
Table 1: Descriptives of CPS data.

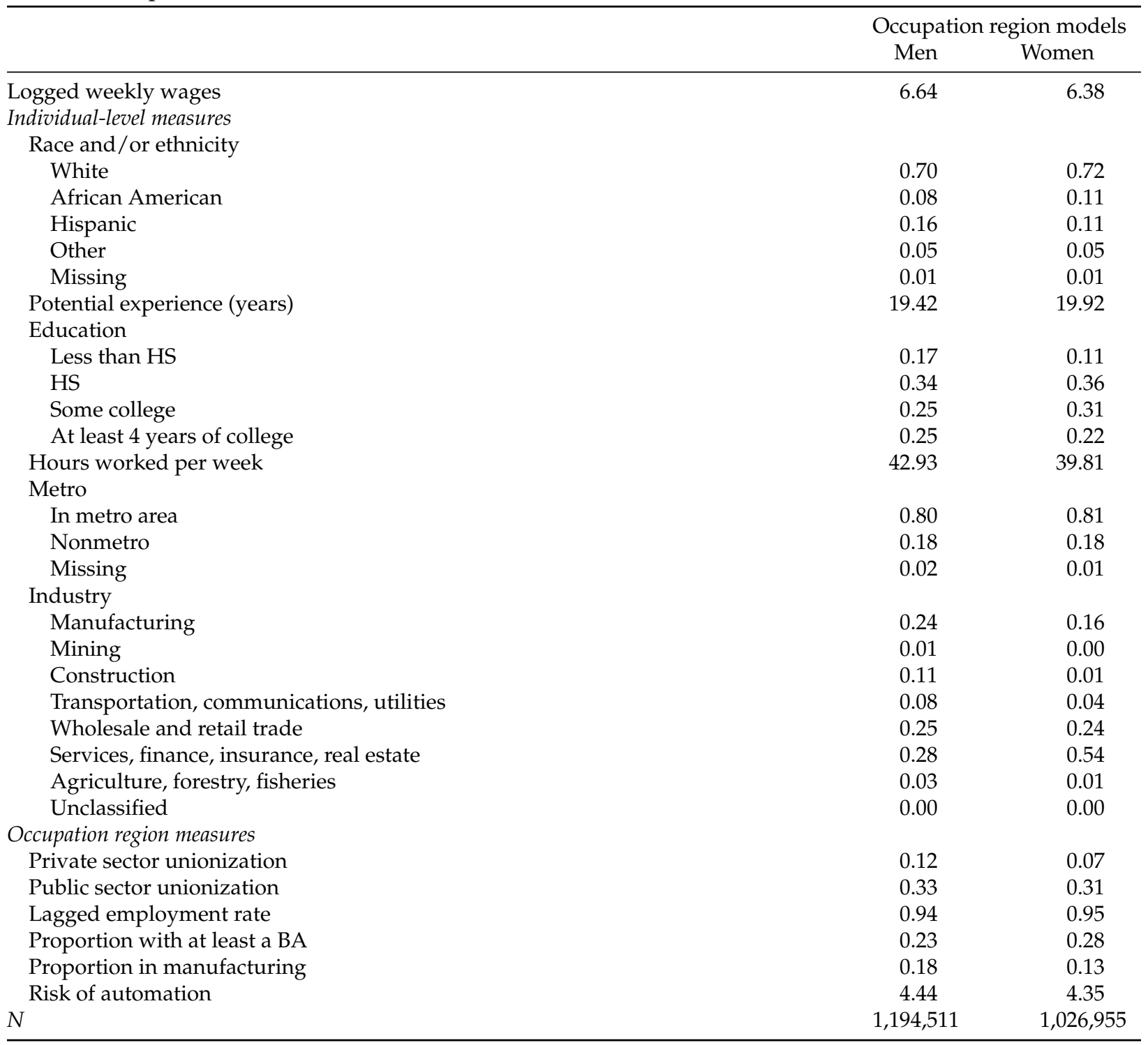

Notes: Data come from the Current Population Survey (CPS) from 1977 to 2015. We rely on the CPS May files for 1977 through 1981 and the CPS-merged outgoing rotation group (ORG) files for 1983 through 2015. Means and proportions are weighted using the appropriate survey weights. BA, bachelor's degree; HS, high school; metro, metropolitan.

As evident in Table 1, log weekly wages are higher for men than women, and the individual-level covariates indicate that the samples are disproportionately white and evenly split between those with at least some college experience and those without. Men average three more hours worked per week than women, and the vast majority of the sample resides in a metropolitan region. At the occupation region level, public sector unionization rates are nearly three times larger than private sector rates for men and more than four times larger among women. Average occupation region educational levels are lower for men than women, whereas the 
Table 2: Effects of private sector occupation region unionization on nonunion, private sector log weekly wages, 1977-2015 (men).

\begin{tabular}{|c|c|c|c|}
\hline & (1) & $(2)$ & (3) \\
\hline \multicolumn{4}{|l|}{ Occupation region controls } \\
\hline Private sector unionization & $\begin{array}{r}0.39^{\dagger} \\
(0.06)\end{array}$ & $\begin{array}{r}0.27^{\dagger} \\
(0.05)\end{array}$ & $\begin{array}{r}0.52^{\dagger} \\
(0.06)\end{array}$ \\
\hline Public sector unionization & $\begin{array}{r}-0.15^{+} \\
(0.03)\end{array}$ & $\begin{array}{c}-0.01 \\
(0.01)\end{array}$ & $\begin{array}{c}-0.00 \\
(0.01)\end{array}$ \\
\hline Lagged employment rate & $\begin{array}{r}1.64^{+} \\
(0.22)\end{array}$ & $\begin{array}{r}0.37^{\dagger} \\
(0.09)\end{array}$ & $\begin{array}{c}0.41^{\dagger} \\
(0.06)\end{array}$ \\
\hline Proportion with at least a BA & $\begin{array}{r}0.56^{\dagger} \\
(0.04)\end{array}$ & $\begin{array}{c}0.54^{\dagger} \\
(0.08)\end{array}$ & $\begin{array}{r}0.39^{\dagger} \\
(0.10)\end{array}$ \\
\hline Proportion in manufacturing & $\begin{array}{c}-0.05 \\
(0.03)\end{array}$ & $\begin{array}{r}-0.15^{*} \\
(0.06)\end{array}$ & $\begin{array}{r}-0.27^{+} \\
(0.05)\end{array}$ \\
\hline Risk of automation & $\begin{array}{c}0.02^{+} \\
(0.00)\end{array}$ & $\begin{array}{c}0.01 \\
(0.02)\end{array}$ & $\begin{array}{c}0.00 \\
(0.02)\end{array}$ \\
\hline \multicolumn{4}{|c|}{ Individual controls } \\
\hline \multicolumn{4}{|c|}{ Race and/or ethnicity (reference = white) } \\
\hline African American & $\begin{array}{r}-0.17^{\dagger} \\
(0.01)\end{array}$ & $\begin{array}{r}-0.16^{\dagger} \\
(0.01)\end{array}$ & $\begin{array}{r}-0.16^{\dagger} \\
(0.01)\end{array}$ \\
\hline Hispanic & $\begin{array}{r}-0.20^{+} \\
(0.01)\end{array}$ & $\begin{array}{r}-0.19^{+} \\
(0.01)\end{array}$ & $\begin{array}{r}-0.18^{\dagger} \\
(0.01)\end{array}$ \\
\hline Other & $\begin{array}{r}-0.11^{\dagger} \\
(0.01)\end{array}$ & $\begin{array}{r}-0.09^{+} \\
(0.01)\end{array}$ & $\begin{array}{r}-0.09^{+} \\
(0.01)\end{array}$ \\
\hline Missing & $\begin{array}{r}-0.02^{+} \\
(0.01)\end{array}$ & $\begin{array}{r}-0.03^{+} \\
(0.01)\end{array}$ & $\begin{array}{r}-0.03^{+} \\
(0.01)\end{array}$ \\
\hline Potential experience & $\begin{array}{c}0.04^{+} \\
(0.00)\end{array}$ & $\begin{array}{c}0.04^{+} \\
(0.00)\end{array}$ & $\begin{array}{c}0.04^{+} \\
(0.00)\end{array}$ \\
\hline Potential experience squared & $\begin{array}{r}-0.00^{+} \\
(0.00)\end{array}$ & $\begin{array}{r}-0.00^{+} \\
(0.00)\end{array}$ & $\begin{array}{r}-0.00^{+} \\
(0.00)\end{array}$ \\
\hline \multicolumn{4}{|c|}{ Education (reference $=$ less than HS) } \\
\hline HS & $\begin{array}{r}0.15^{\dagger} \\
(0.01)\end{array}$ & $\begin{array}{c}0.14^{\dagger} \\
(0.00)\end{array}$ & $\begin{array}{c}0.14^{\dagger} \\
(0.00)\end{array}$ \\
\hline Some college & $\begin{array}{r}0.26^{\dagger} \\
(0.01)\end{array}$ & $\begin{array}{r}0.24^{\dagger} \\
(0.01)\end{array}$ & $\begin{array}{r}0.24^{\dagger} \\
(0.01)\end{array}$ \\
\hline At least 4 years of college & $\begin{array}{r}0.52^{\dagger} \\
(0.01)\end{array}$ & $\begin{array}{r}0.50^{\dagger} \\
(0.01)\end{array}$ & $\begin{array}{r}0.49^{\dagger} \\
(0.01)\end{array}$ \\
\hline Hours worked per week & $\begin{array}{c}0.02^{+} \\
(0.00)\end{array}$ & $\begin{array}{c}0.02^{+} \\
(0.00)\end{array}$ & $\begin{array}{c}0.02^{+} \\
(0.00)\end{array}$ \\
\hline \multicolumn{4}{|l|}{ Metro (reference $=$ in metro area) } \\
\hline Nonmetro & $\begin{array}{r}-0.12^{\dagger} \\
(0.01)\end{array}$ & $\begin{array}{r}-0.12^{\dagger} \\
(0.01)\end{array}$ & $\begin{array}{r}-0.12^{\dagger} \\
(0.01)\end{array}$ \\
\hline Missing & $\begin{array}{r}-0.07^{+} \\
(0.01)\end{array}$ & $\begin{array}{r}-0.07^{+} \\
(0.01)\end{array}$ & $\begin{array}{r}-0.08^{\dagger} \\
(0.01)\end{array}$ \\
\hline Intercept & $\begin{array}{r}3.63^{+} \\
(0.19)\end{array}$ & $\begin{array}{r}4.94^{+} \\
(0.12)\end{array}$ & $\begin{array}{c}4.92^{\dagger} \\
(0.10)\end{array}$ \\
\hline Occupation FE & No & Yes & No \\
\hline Region FE & Yes & Yes & No \\
\hline Occupation region $\mathrm{FE}$ & No & No & Yes \\
\hline$N$ & $1,194,511$ & $1,194,511$ & $1,194,511$ \\
\hline Number of parameters & 70 & 94 & 278 \\
\hline$R^{2}$ & 0.51 & 0.52 & 0.52 \\
\hline
\end{tabular}


Table 3: Effects of private sector occupation region unionization on nonunion, private sector log weekly wages, 1977-2015 (women).

\begin{tabular}{|c|c|c|c|}
\hline & $(1)$ & $(2)$ & (3) \\
\hline \multicolumn{4}{|l|}{ Occupation region controls } \\
\hline Private sector unionization & $\begin{array}{c}0.27^{\dagger} \\
(0.09)\end{array}$ & $\begin{array}{c}0.23^{\dagger} \\
(0.08)\end{array}$ & $\begin{array}{c}0.39^{\dagger} \\
(0.06)\end{array}$ \\
\hline Public sector unionization & $\begin{array}{r}-0.08^{\dagger} \\
(0.03)\end{array}$ & $\begin{array}{c}0.00 \\
(0.02)\end{array}$ & $\begin{array}{c}-0.00 \\
(0.01)\end{array}$ \\
\hline Lagged employment rate & $\begin{array}{r}1.75^{\dagger} \\
(0.23)\end{array}$ & $\begin{array}{r}0.35^{\dagger} \\
(0.07)\end{array}$ & $\begin{array}{r}0.20^{\dagger} \\
(0.06)\end{array}$ \\
\hline Proportion with at least a BA & $\begin{array}{r}0.54^{\dagger} \\
(0.04)\end{array}$ & $\begin{array}{c}0.38^{+} \\
(0.07)\end{array}$ & $\begin{array}{c}0.32^{\dagger} \\
(0.07)\end{array}$ \\
\hline Proportion in manufacturing & $\begin{array}{r}-0.16^{+} \\
(0.04)\end{array}$ & $\begin{array}{c}-0.03 \\
(0.07)\end{array}$ & $\begin{array}{r}-0.26^{+} \\
(0.06)\end{array}$ \\
\hline Risk of automation & $\begin{array}{r}0.04^{+} \\
(0.01)\end{array}$ & $\begin{array}{c}0.04^{+} \\
(0.01)\end{array}$ & $\begin{array}{c}0.04^{+} \\
(0.01)\end{array}$ \\
\hline \multicolumn{4}{|l|}{ Individual controls } \\
\hline \multicolumn{4}{|c|}{ Race and/or ethnicity (reference = white) } \\
\hline African American & $\begin{array}{r}-0.07^{+} \\
(0.01)\end{array}$ & $\begin{array}{r}-0.07^{+} \\
(0.01)\end{array}$ & $\begin{array}{r}-0.07^{+} \\
(0.01)\end{array}$ \\
\hline Hispanic & $\begin{array}{r}-0.13^{+} \\
(0.01)\end{array}$ & $\begin{array}{r}-0.12^{\dagger} \\
(0.01)\end{array}$ & $\begin{array}{r}-0.12^{+} \\
(0.01)\end{array}$ \\
\hline Other & $\begin{array}{r}-0.05^{+} \\
(0.01)\end{array}$ & $\begin{array}{r}-0.05^{\dagger} \\
(0.01)\end{array}$ & $\begin{array}{r}-0.05^{\dagger} \\
(0.01)\end{array}$ \\
\hline Missing & $\begin{array}{r}-0.02^{*} \\
(0.01)\end{array}$ & $\begin{array}{r}-0.02^{*} \\
(0.01)\end{array}$ & $\begin{array}{r}-0.02^{*} \\
(0.01)\end{array}$ \\
\hline Potential experience & $\begin{array}{c}0.02^{+} \\
(0.00)\end{array}$ & $\begin{array}{c}0.02^{+} \\
(0.00)\end{array}$ & $\begin{array}{c}0.02^{\dagger} \\
(0.00)\end{array}$ \\
\hline Potential experience squared & $\begin{array}{r}-0.00^{+} \\
(0.00)\end{array}$ & $\begin{array}{r}-0.00^{+} \\
(0.00)\end{array}$ & $\begin{array}{r}-0.00^{+} \\
(0.00)\end{array}$ \\
\hline \multicolumn{4}{|c|}{ Education (reference = less than HS) } \\
\hline HS & $\begin{array}{r}0.13^{\dagger} \\
(0.01)\end{array}$ & $\begin{array}{r}0.12^{\dagger} \\
(0.01)\end{array}$ & $\begin{array}{r}0.12^{\dagger} \\
(0.01)\end{array}$ \\
\hline Some college & $\begin{array}{c}0.23^{\dagger} \\
(0.01)\end{array}$ & $\begin{array}{r}0.22^{+} \\
(0.01)\end{array}$ & $\begin{array}{r}0.22^{+} \\
(0.01)\end{array}$ \\
\hline At least 4 years of college & $\begin{array}{c}0.45^{\dagger} \\
(0.02)\end{array}$ & $\begin{array}{c}0.44^{\dagger} \\
(0.01)\end{array}$ & $\begin{array}{c}0.44^{\dagger} \\
(0.01)\end{array}$ \\
\hline Hours worked per week & $\begin{array}{r}0.03^{\dagger} \\
(0.00)\end{array}$ & $\begin{array}{c}0.03^{\dagger} \\
(0.00)\end{array}$ & $\begin{array}{r}0.03^{\dagger} \\
(0.00)\end{array}$ \\
\hline \multicolumn{4}{|l|}{ Metro $($ reference $=$ in metro area $)$} \\
\hline Nonmetro & $\begin{array}{r}-0.14^{+} \\
(0.01)\end{array}$ & $\begin{array}{r}-0.14^{\dagger} \\
(0.01)\end{array}$ & $\begin{array}{r}-0.14^{\dagger} \\
(0.01)\end{array}$ \\
\hline Missing & $\begin{array}{r}-0.10^{+} \\
(0.01)\end{array}$ & $\begin{array}{r}-0.10^{\dagger} \\
(0.01)\end{array}$ & $\begin{array}{r}-0.10^{\dagger} \\
(0.01)\end{array}$ \\
\hline Intercept & $\begin{array}{r}3.16^{+} \\
(0.20)\end{array}$ & $\begin{array}{c}4.54^{\dagger} \\
(0.10)\end{array}$ & $\begin{array}{r}4.65^{\dagger} \\
(0.10)\end{array}$ \\
\hline Occupation FE & No & Yes & No \\
\hline Region FE & Yes & Yes & No \\
\hline Occupation region FE & No & No & Yes \\
\hline N & $1,026,955$ & $1,026,955$ & $1,026,955$ \\
\hline Number of parameters & 70 & 94 & 278 \\
\hline$R^{2}$ & 0.50 & 0.51 & 0.51 \\
\hline
\end{tabular}

Notes: Robust standard errors clustered by occupation region are in parentheses. All models include year and industry fixed effects. Statistical significance (two-tailed tests) is indicated by a $p$ value. ${ }^{*} p<0.05,{ }^{\dagger} p<0.01$. BA, bachelor's degree; FE, fixed effects; HS, high school; metro, metropolitan. 
fraction of workers in the manufacturing sector in each occupation region is higher for men. Occupation region employment rates show little difference by gender.

\section{Results}

In Figure 2, we plot the bivariate relationship between private sector unionization rates and median wages for nonunion private sector workers for each occupation region in 1977 and 2015. Each dot represents an occupation region's private sector unionization rate ( $\mathrm{x}$ axis) and median log weekly wage for nonunion, full-time, private sector workers ( $\mathrm{y}$ axis). The figure provides preliminary evidence of a positive association between private sector union strength and nonunion private sector wages, especially among men. In 1977, private sector unionization rates at the occupation region level ranged from 0 percent (in fields such as food service in the Gulf Coast states) to nearly 90 percent (mining in West Virginia and other mid-Southern states), and median wages were generally higher in the occupation regions with greater union strength. By 2015, severe deunionization is evident, with only one occupation region registering a unionization rate greater than 50 percent. As the labor movement receded from the private sector, the correlation between nonunion wages and union density declines appreciably. The picture is generally similar with women, although base wage rates are lower in both periods, and the slope of the 1977 relationship between wages and private sector organizing is a bit flatter. $^{5}$

We begin our formal analyses by testing whether the association between private sector union strength at the occupation and occupation region levels and nonunion pay remains after adjusting for a range of occupation region and individual controls. Tables 2 and 3 present the results from a series of models of log weekly wages. Table 2 shows the results for male nonunion private sector workers; Table 3 shows the results for women. All models include year dummies and our set core of occupation region controls, such as the proportion in manufacturing, the lagged employment rate, and the proportion with a bachelor's degree or more. These measures help differentiate the relationship between private sector unionization and nonunion pay from other key explanations for wage trends in the private sector. We also adjust for public sector union strength at the occupation region level, ensuring that any private sector union effects our models reveal are not proxying for the influence of public sector labor organizations on private sector pay. All models also adjust for common individual-level correlates of wages.

Model 1 of Table 2 does not include occupation identifiers but does control for respondent industry with a set of 8 industry dummies. In this base model, the private sector union coefficient is positive and significantly associated with nonunion men's wages. Surprisingly, in this specification, public sector union strength at the occupation region level is negatively related to men's wages, although the coefficient is not significant in the other models. Other occupation region effects that are positively related to individual wages include the lagged employment rate, proportion with a bachelor's degree or more, and the proportion at risk of automation. A higher employment rate in an occupation region boosts wages by increasing workers' bargaining power vis-à-vis management. What explains the occupation 
(a) Men

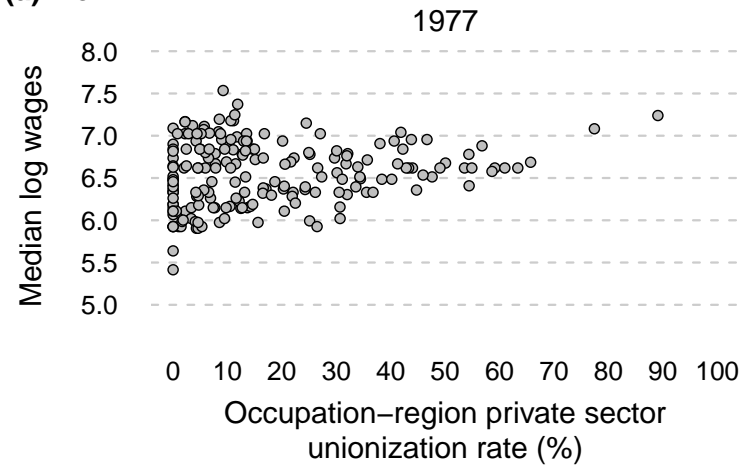

(b) Women

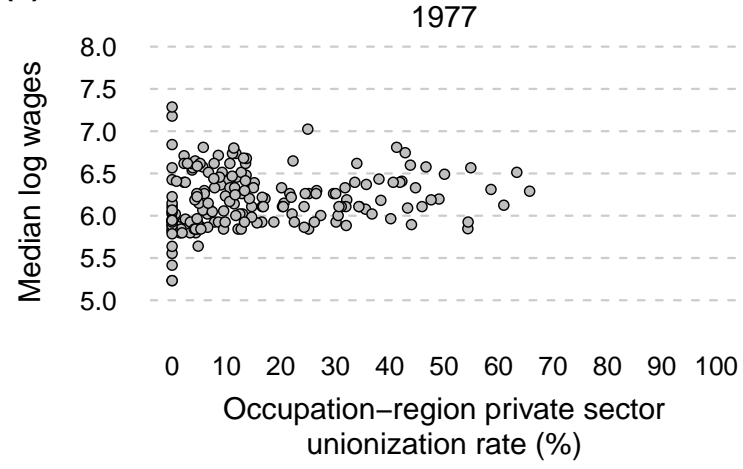

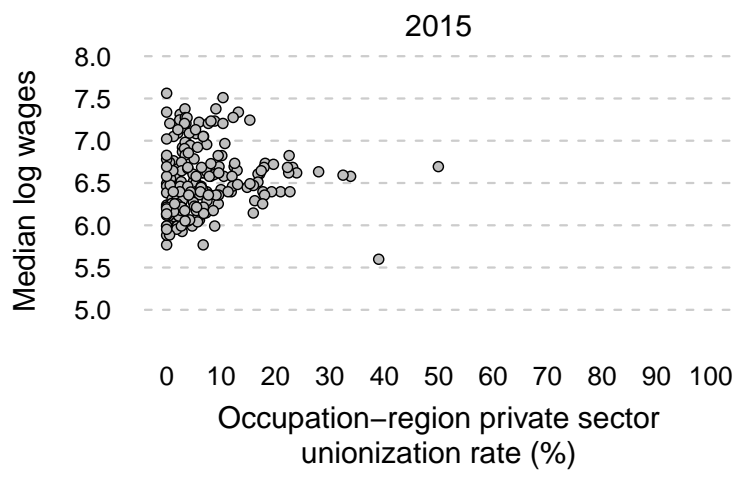

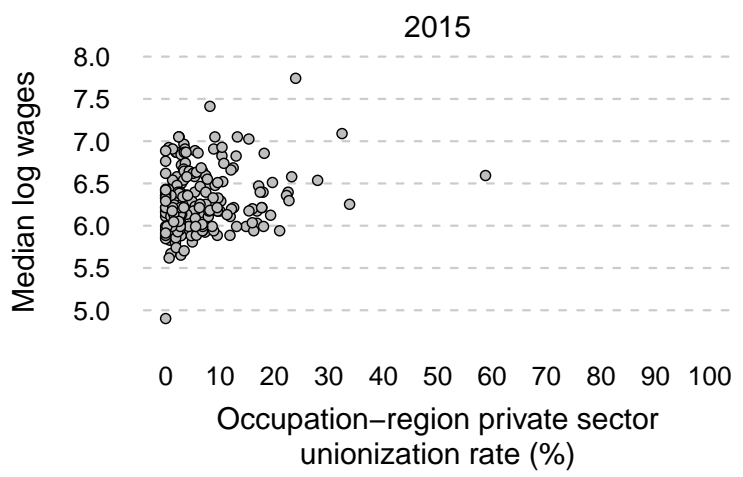

Figure 2: Occupation region unionization rate and nonunion median log weekly wages.

region education effect? Though the occupation region and individual education measures are correlated, the average education level of an occupation can increase occupational rewards independently of an individual's own education. Whether educational credentials represent actual skills required to carry out the tasks of a particular occupation or function as a signal with cultural relevance, Weeden (2002:Table 4) demonstrates that they represent an important source of occupational closure and that higher average educational levels are related to higher wages. Similar to our finding, Weeden's analysis indicates that the proportion of workers in an occupation with at least some college has a positive and statistically significant relationship with wages when controlling for an individual's own educational level.

Finally, the positive relationship between the proportion of workers in a given occupation region who are at risk of automation and wages is likely due to the distribution of routine task content along the wage continuum as well as our sample restrictions. Routine task scores are highest in middle-wage jobs and lowest in the lower- and higher-wage tails (Autor and Dorn 2013). In our models, we exclude many of the highest earners by dropping upper-level managers and executives, thereby inducing a modest positive relationship between our automation measure and the wages of those in our sample. The individual-level controls operate as 
expected, with higher wages for nonunion white workers relative to other racial and/or ethnic groups, for more educated workers, and for workers in central cities.

What this base model lacks are adjustments for respondent occupation. Given the importance of occupations in structuring pay (Weeden 2002) and how unionization is patterned by occupation in the U.S. context, failing to adjust for respondent occupation may bias our unionization coefficient. Model 2 includes occupation fixed effects, which reduces the size of the private sector union coefficient by 31 percent. However, it is still positively and significantly related to nonunion wages. The inclusion of occupation fixed effects renders the public sector union strength coefficient nonsignificant, and now, the proportion in manufacturing coefficient attains significance and is negatively related to nonunion worker pay. The additional occupation controls of model 2 do little to shift the sign or significance of the individual-level controls. In model 3 , we add occupation region fixed effects, constraining the variation in pay to be within occupation region, over time. Here, too, we see a positive, significant relationship between private sector union strength and nonunion workers' pay, and the coefficient nearly doubles in magnitude compared with model 2. Occupation region employment levels also remain positively related to wages in this final model, as does the proportion of respondents with a bachelor's degree or more. We again find a significant and negative relationship between the proportion of each occupation region working in manufacturing industries and average pay for nonunion workers.

Table 3 presents results from a similar set of analyses for nonunion private sector women. In general, the relationships between our core covariates and women's wages are similar to those of men, with a few exceptions. In all three models of Table 3, the measure of the proportion who are at risk of automation is positively signed and significantly related to weekly pay. Among the individual-level controls, whites' wage premium is generally lower for women. Critically for our purposes, in all three specifications, private sector unionization at the occupation region level is significantly and positively related to nonunion women's pay.

In a series of supplemental models (available upon request), we relax the assumption that the effects of the occupation region factors are stable over time by interacting them with a linear year specification and, in separate models, with year dummies. The inclusion of these interactions does not improve model fit markedly, and the private sector unionization coefficients remain positive and significantly related to nonunion workers' wages. The private sector unionization effect for men is relatively stable over time and shows a very slight decrease for women in the last few years of our series.

In other supplemental tests, we interacted individual-level education with year to capture the rising returns to education (particularly a bachelor's degree) over time. To account for the possibility that there are differences by skill level in the relationship between private sector union density and wages, we interacted private union density with worker education. Men and women with lower levels of education appear to benefit more in terms of wage gains in occupation regions with higher levels of private sector unionization, which is consistent with prior research finding larger relative union wage premiums for less skilled workers (Card 1996). Additionally, we separately interacted private sector union density with the occupa- 
tion region measures of the share of workers with at least a bachelor's degree, the share of workers in manufacturing, and the risk of automation to test whether the union effect is stronger in labor markets in which these other measures are relatively high or low. For men across these models, the union effect appears stronger in occupation regions with lower shares of workers with at least a bachelor's degree. The union effect appears to be stronger for women in labor markets with lower levels of education as well as a lower risk of automation. A separate model interacts all of the occupation region covariates with a linear measure of time. Importantly, in none of these robustness checks are our core findings substantively changed. In all of these supplemental models, the relationship between private sector unionization and log weekly wages of nonunion men and women working in the private sector remains consistent in terms of direction, magnitude, and statistical significance.

What do these union coefficients translate to in terms of actual dollars? To generate predicted wages in level form, we reestimate GLM versions of the six models from Tables 2 and 3 specifying a log-link and gamma distribution family (we present the full results of these models in Tables A1 and A2 of the Data Appendix of the online supplement). From these models, we generate estimates of what private sector nonunion wages would be if private sector unionization remained as strong in 2015 as it was in 1977, the first year of our series. We estimate these counterfactuals by first predicting mean weekly wages based on model 3's specification, allowing unionization to vary at the occupation region level as it does in the data. Next, we fix unionization rates at their 1977 occupation region densities, allowing all other controls to vary, and predict mean weekly wages under this counterfactual scenario. Subtracting the counterfactual wages from the predicted wages under the first scenario gives us our estimate of the size of the union effect (Rosenfeld and Kleykamp 2012; Rosenfeld et al. 2016 follow a similar approach).

The size of the union effect is substantial, especially for men. We estimate that weekly wages would be approximately $\$ 61$ - or 6 percent-higher for nonunion private sector men if private sector union densities were as high in 2015 as they were in 1977. Over the course of a year, this would result in a wage gain of $\$ 3,172$. Among women, the counterfactual predictions reveal that a nonunion worker would earn $\$ 18$ more weekly had unions not declined since 1977, or \$936 annually. These counterfactual estimates are consistent with recent related research (Rosenfeld et al. 2016:Figure C) despite the more stringent specification of our model and different level of analysis.

Why do the predicted probabilities produce a union effect for women that is less than one-third of the magnitude of that for men? Part of the disparity stems from occupational segregation: Women are disproportionately concentrated in lightly organized occupations, lowering the overall union influence on nonunion women's pay. In Figure 3, we plot the size of the private sector union effect (described above) for a few key occupation regions. The figure displays the differences between our counterfactual estimates that assume 1977 unionization levels and our modelpredicted estimates in which unionization rates decline over time, as the data indicate. The bars then represent the union effect for four selected occupational groups in each of our nine regions. 
(a) Men

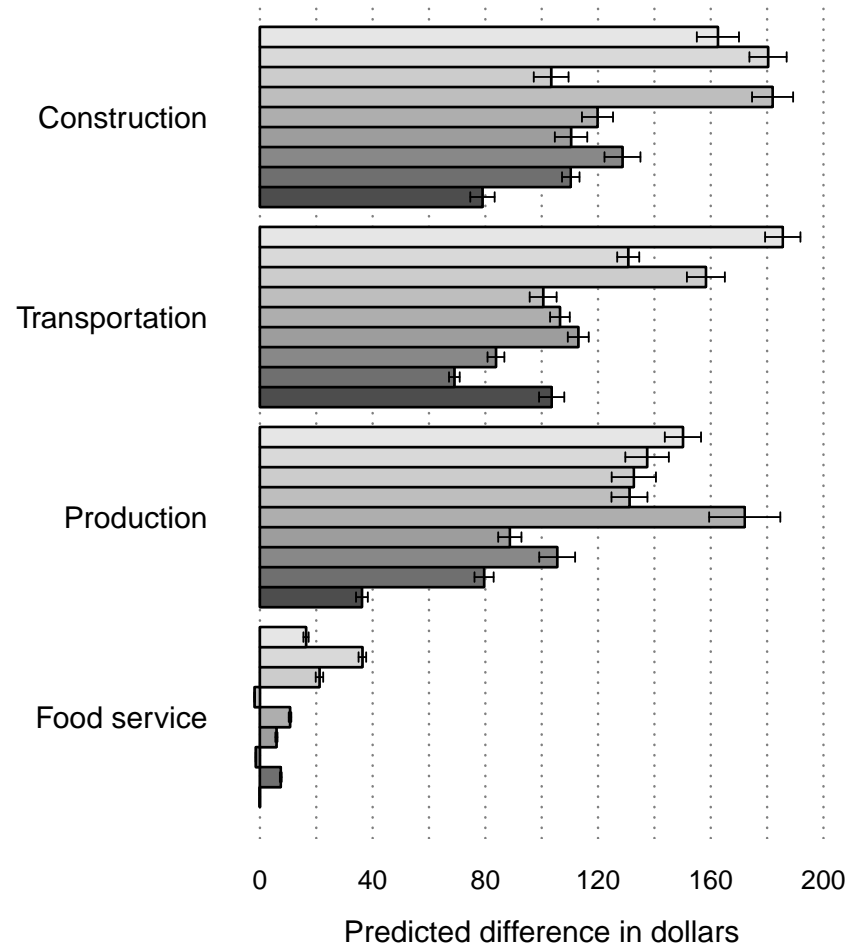

(b) Women

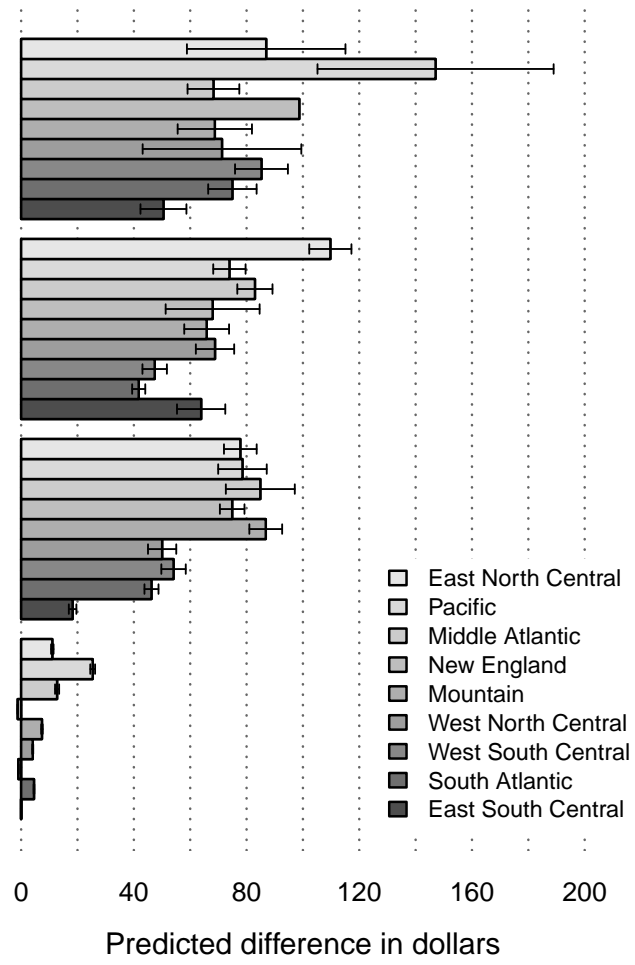

Figure 3: Predicted weekly wage differences for selected occupations and regions. Bars indicate the difference in dollars in 2015 between the model-predicted average weekly wages and the counterfactual wages for workers in each region within selected occupations. Lines denote $95 \%$ confidence intervals around those differences.

The figure shows large union effects in occupations prone to the forces of automation and offshoring (such as production work) alongside occupations in which offshoring is not a threat (construction and transportation) and in which, to date at least, automation has not changed the nature of the job all that appreciably (transportation). As shown, weekly wages for nonunion workers in all three of these major occupations would have been much higher absent deunionization, although union effects in the Southern regions tend to be smaller given lower densities and wage rates. And, as shown, the effects are also substantial for women, demonstrating that nonunion women in highly organized occupations enjoy the spillovers that a strong union presence can provide. Yet comparably few women are in these occupations, as evidenced by the wider confidence intervals surrounding the point estimates in our analysis of women in transportation and especially construction. Women, meanwhile, make up more than half of food service workers, an occupation in which unions never had much presence.

These analyses indicate that private sector unions are strongly associated with nonunion pay at the occupation and occupation region levels. The union effect is 
robust to the inclusion of numerous controls, including measures for the increasing demand for skilled workers, the threat of automation, and the decline of manufacturing industries. Moreover, the union effect is large in occupations not prone to other prominent explanations for stagnating pay. And the analyses demonstrate that strong private sector unions helped boost the pay of women workers, at least those in occupations and regions in which unions had a significant presence.

\section{Discussion and Conclusion}

Analyzing data on millions of workers spanning nearly four decades, we find a robust, positive, and substantively large private sector union effect on the wages of nonunion men and women at the occupation and occupation region levels of analysis. The private sector union effects are robust to the inclusion of controls for manufacturing decline, automation, rising skill demands, as well as occupation and occupation region fixed effects. Prior research on the topic fails to separate union effects on nonunion pay from these other forces affecting nonunion wages, forces that have also been implicated in the decades-long decline in private sector union memberships. Thus, the first innovation of this article is to demonstrate the independent influence of private sector union strength on nonunion private sector pay.

Our measures of the other dominant explanations for wage stagnation and rising inequality are, of course, proxies, and may not fully account for the interrelationships between offshoring, automation, rising demand for skill, and union decline. This, we believe, is why an occupational analysis of union spillover is so important. Not only does it align our work with research on the occupational antecedents of rising inequality (Mouw and Kalleberg 2010; Weeden 2002), it allows us to disaggregate union spillover effects by occupational category. Focusing on occupations not subject to offshoring and automation provides a crucial check on how wide union spillover effects extend and whether they remain substantial outside of occupations undergoing a whole host of transformations in the late twentieth and early twenty-first centuries. Figure 3 demonstrates that union spillover effects are, indeed, widespread, with union decline buffeting nonunion workers across occupations that are both prey to and protected from globalization and rapid technological change.

Unaddressed in prior research on the topic is why union spillover is so much more substantial for male workers. This finding is curious because the theoretical pathways - whether they be cultural, economic, or political—should apply to women workers' wages as well as men's. What our investigation demonstrates is that at least some of this finding stems from occupational segregation. A focus within occupations shows substantial spillover magnitudes for nonunion women in those occupations in which private sector unions were once strong. Comparatively, however, there were far fewer women in these occupations, dampening the overall effect of union strength on nonunion women's wages.

That said, the spillover effect sizes within occupations remain, on average, larger for men than women (see Figure 3). Future research utilizing fine-grained occupational breakdowns should investigate whether the finding holds in more 
detailed occupations. We suspect that our set of 24 occupations remains too broad to capture all effects of occupational segregation. If, for example, women are relegated to more routine and less remunerated jobs within transportation and construction, then we should not expect similarly sized union spillover effects. Analyses looking within these relatively broad occupational categories should help distinguish occupational segregation from other processes generating differential spillovers for men and women.

Our focus on occupational dynamics and their relations to gender pay distributions represents an important advancement in quantitative studies of union decline. Despite the lack of much overlap in the existing quantitative literature, from a theoretical perspective, the dynamics of occupational segregation and union power are inextricably linked. In key industries, organized labor often worked alongside management in maintaining gendered divisions of labor. Following the Second World War, for example, the United Automobile Workers (UAW) failed to challenge the mass replacement of women factory workers with returning male soldiers (Milkman 2016). In the private sector, union fortunes suffered the most in heavily male occupations, such as automobile manufacturing and mining. One paradox of the interplay of gender segregation and union power is that absent organized labor's demise, all else being equal, gender pay gaps would likely be larger. If, on the other hand, barriers to occupational sex segregation had fallen further and unions remained strong in the private sector, a much different story could have unfolded. Women's disproportionate concentration in nonunion, low-paid service occupations, along with their sizable growth in the professions, has resulted in an explosion of income inequality among women. Strong unions, and the accompanying spillover effects, would have buttressed the pay of nonprofessional women, lowering intragender inequality. Meanwhile, women's sizable presence in those heavily unionized private sector occupations disproportionately held by men would have helped narrow intergender wage gaps.

Our findings at the occupation and occupation region levels are also robust to controls for public sector union strength. Prior research fails to control for public sector union density despite the fact that today, roughly half of all union members work for the state and many public sector unions are incredibly powerful political actors. Past findings of strong private sector union spillovers may, in fact, be picking up the influence of public sector union strength on private sector nonunion pay, especially in recent years, when the overall public sector union density rate is five times higher than in the private sector. Moreover, although certain public sector occupations, such as policing and fire protection, lack similar jobs in the private sector, other large occupations in the government sector, such as teachers, nurses, and administrative assistants, have plenty of private sector counterparts, making it important to adjust for public sector union strength in models investigating private sector spillover effects.

Given the size and strength of many public sector unions, along with sizable private sector workforces in many occupations with a large public sector union presence, the lack of evidence for public sector spillover effects in our occupational-level analysis is surprising. It may be that an occupational level of analysis that spans state lines fails to detect public sector union spillover effects on private sector work- 
ers given how patterned public sector densities are by state. With few exceptions (such as the railway industry), federal law-most notably, the National Labor Relations Act (NLRA) - governs collective bargaining in the private sector. There is no corollary federal legislation for public sector unions. Public sector unions emerged later than private sector ones, partly as a result of state-level actions granting varying degrees of license for state and local government workers to bargain with their employers. Researchers disagree about the relative impact of these policy decisions on initial public sector union growth, with some arguing that the legislation was decisive (Freeman 1986; Freeman and Ichniowski 1988) and others suggesting that organization and mobilization among government employees often preceded and helped precipitate union-friendly state laws (Belman, Heywood, and Lund 1997; Goldfield and Bromsen 2013). But there is little debate about the contemporary correlation between public sector union power and the comprehensiveness (or lack thereof) of state laws governing collective bargaining (Farber 2005; Freeman 2012). A focus on occupational (or occupation region) differences in public sector unionization ignores the tight coupling of public sector union strength with state boundaries.

As with any investigation of such scope, other shortcomings remain. Future research, especially of the historical and qualitative variety, should seek to distinguish between the various channels through which unions help raise nonunion pay. Large-scale, employee-based data sets, such as the CPS, do not allow us to differentiate between economic and norm-based and political mechanisms, especially given the lack of employer information in the surveys. In supplemental tests (available upon request), we reran the core analyses at the occupation-state level to see whether the spillover effects uncovered at the occupation region level are evident at a more politically meaningful level of analysis. Results of these tests suggest that spillovers at the occupation-state level are largely limited to nonunion, private sector men. These more mixed results suggest to us that in recent decades, economic and norm-based channels were likely the primary means through which unions raised nonunion pay, but more precise tests of these potential mechanisms are needed.

Limitations aside, our analyses provide further evidence of the robust and substantively large impact of private sector union strength on nonunion pay. That the influence of private sector unions remains robust to the inclusion of controls for manufacturing decline, the threat of automation, and the rising demand for skilled labor suggests to us that the plight of organized labor should be seen as a central culprit for wage stagnation and growing inequality in the twenty-first century economy. That these union effects are large for women as well as men points to the importance of labor unions in supporting the wages of all unorganized workers, not just men, at least in those occupations in which private sector unions were once strong. And the robustness of the private sector union effects even after adjusting for public sector union strength points to the unique role private sector unions played in supporting the wages of wide swaths of the American workforce prior to their dismantling. 


\section{Notes}

1 In his final State of the Union address, President Obama referenced a number of forces, including widespread automation and offshoring that "have squeezed workers, even when they have jobs, even when the economy is growing." See here for the full transcript: https://obamawhitehouse .archives.gov/the-press-office/2016/01/12/remarkspresident-barack-obama-\%E2\%80\%93-prepared-delivery-state-union-address.

2 For the board's final report, see https://on.ny.gov/2M8n4cG.

3 We explored two additional ways of operationalizing the risk for automation and obtained substantively similar results across specifications. First, we created a measure of routine task intensity by subtracting the natural log of both manual task content and abstract task content from the natural log of routine task content to address the concern that some occupations have high values on more than one type of task. Second, we calculated a measure of routine employment share, defined as the proportion of workers in a given occupation region who work in an occupation in the top one-third of routine task intensity. See Autor and Dorn (2013) for additional details on the construction of these measures.

4 The CPS does not ask about workforce experience, so we define potential experience as age minus years of education minus four, approximating the potential time spent out of school. Although it is more standard to define potential experience as age minus education minus six, doing so results in a significant number of negative values given the minimum age of 16 for our sample. Using the standard measure and converting negative values to zeroes produces similar results.

5 The figure plots the overall unionization rate (i.e., not disaggregated by sex) for each occupation region. The differences in unionization rates between men and women that are evident in the figure reflect the lack of any women or men in certain occupation regions. For example, in our CPS sample, there were no female miners in West Virginia and other mid-Southern states in 1977.

\section{References}

Ahlquist, John S. 2017. “Labor Unions, Political Representation, and Economic Inequality." Annual Review of Political Science 20:409-432.

Autor, David and David Dorn. 2013. "The Growth of Low Skill Service Jobs and the Polarization of the U.S. Labor Market." American Economic Review 103:1553-1597.

Baker, Dean. 2007. The Productivity to Paycheck Gap: What the Data Show. Washington, DC: Center for Economic and Policy Research.

Belman, Dale, John S. Heywood, and John Lund. 1997. "Public Sector Earnings and the Extent of Unionization." Industrial and Labor Relations Review 50:610-628.

Brueckner, Jan K. and David Neumark. 2014. "Beaches, Sunshine, and Public Sector Pay: Theory and Evidence on Amenities and Rent Extraction by Government Workers." American Economic Journal: Economic Policy 6:198-230.

Card, David. 1996. "The Effect of Unions on the Structure of Wages: A Longitudinal Analysis." Econometrica 64:957-979.

Dorn, David. 2009. Essays on Inequality, Spatial Interaction, and the Demand for Skills. Master's thesis, University of St. Gallen. 
Duan, Naihua. 1983. "Smearing Estimate: A Nonparametric Retransformation Method." Journal of the American Statistical Association 78:605-610.

Farber, Henry S. 2005. "Nonunion Wage Rates and the Threat of Unionization." Industrial and Labor Relations Review 58:335-352.

Foulkes, Fred K. 1980. Personnel Policies in Large Nonunion Companies. Upper Saddle River, NJ: Prentice-Hall.

Freeman, Richard B. 1986. "Unionism Comes to the Public Sector." Journal of Economic Literature 24:41-86.

Freeman, Richard B. 2012. "The War Against Public Sector Collective Bargaining in the U.S." Journal of Industrial Relations 54:386-408.

Freeman, Richard B. and Casey Ichniowski. 1988. When Public Sector Workers Unionize. Chicago, IL: The University of Chicago Press.

Goldfield, Michael and Amy Bromsen. 2013. "The Changing Landscape of U.S. Unions in Historical and Theoretical Perspective." Annual Review of Political Science 16:231-257.

Hirsch, Barry T. and David A. Macpherson. 2003. “Union Membership and Coverage Database from the Current Population Survey: Note." Industrial and Labor Relations Review 56:349-354.

Hirsch, Barry T. and David A. Macpherson. 2017. Union Membership and Earnings Data Book: Compilations from the Current Population Survey. Washington, DC: Bureau of National Affairs.

Hirsch, Barry T., David A. Macpherson, and Wayne G. Vroman. 2001. "Estimates of Union Density by State." Monthly Labor Review 124:51-55.

Hirsch, Barry T. and Edward J. Schumacher. 2004. "Match Bias in Wage Gap Estimates Due to Earnings Imputation." Journal of Labor Economics 22:689-722.

Hollister, Matissa N. and Kristin E. Smith. 2014. "Unmasking the Conflicting Trends in Job Tenure by Gender in the United States, 1983-2008." American Sociological Review 79:159-181.

Jacoby, Sanford M. 1997. Modern Manors: Welfare Capitalism since the New Deal. Princeton, NJ: Princeton University Press.

Jaumotte, Florence and Carolina Osorio Buitron. 2015. "Power from the People." Finance and Development 52:29-31.

Kleykamp, Meredith. 2013. “Unemployment, Earnings, and Enrollment among Post 9/11 Veterans." Social Science Research 42:836-851.

Kochan, Thomas A. 1973. "Correlates of State Public Employee Bargaining Laws." Industrial Relations 12:322-337.

Leicht, Kevin T. 1989. “On the Estimation of Union Threat Effects." American Sociological Review 54:1035-1047.

Lemieux, Thomas. 2006. “Increasing Residual Wage Inequality: Composition Effects, Noisy Data, or Rising Demand for Skill?” American Economic Review 96:461-498. 
Lewin, David, Jeffrey Keefe, and Thomas A. Kochan. 2012. "The New Great Debate about Unionism and Collective Bargaining in U.S. State and Local Governments." Industrial and Labor Relations Review 65:749-778.

Mandel, Hadas. 2013. “Up the Down Staircase: Women's Upward Mobility and the Wage Penalty for Occupational Feminization, 1970-2007." Social Forces 91:1183-1207.

Milkman, Ruth. 2016. On Gender, Labor, and Inequality. Champaign, IL: University of Illinois Press.

Mouw, Ted and Arne L. Kalleberg. 2010. “Occupations and the Structure of Wage Inequality in the United States, 1980s to 2000s." American Sociological Review 75:402-431.

National Labor Relations Board. 1997. Basic Guide to the National Labor Relations Act. Washington, DC: U.S. Government Printing Office.

Percheski, Christine. 2008. “Opting Out? Cohort Differences in Professional Women's Employment Rates from 1960 to 2005." American Sociological Review 73:497-517.

Podgursky, Michael. 1986. “Unions, Establishment Size, and Intra-Industry Threat Effects.” Industrial and Labor Relations Review 39:277-284.

Rosenfeld, Jake, Patrick Denice, and Jennifer Laird. 2016. Union Decline Lowers Wages of Nonunion Workers. Washington, DC: Economic Policy Institute.

Rosenfeld, Jake and Meredith Kleykamp. 2012. “Organized Labor and Racial Wage Inequality in the United States." American Journal of Sociology 117:1460-1502.

Shin, Taekjin. 2014. "Explaining Pay Disparities between Executives and Nonexecutive Employees: A Relative Bargaining Power Approach." Social Forces 92:1339-1372.

Weeden, Kim A. 2002. "Why Do Some Occupations Pay More than Others? Social Closure and Earnings Inequality in the United States." American Journal of Sociology 108:55-101.

Western, Bruce and Jake Rosenfeld. 2011. “Unions, Norms, and the Rise in U.S. Wage Inequality." American Sociological Review 76:513-537.

Acknowledgements: Partial support for this research came from a Eunice Kennedy Shriver National Institute of Child Health and Human Development research infrastructure grant (P2C HD042828) to the Center for Studies in Demography and Ecology at the University of Washington.

Patrick Denice: Department of Sociology, The University of Western Ontario.

E-mail: pdenice@uwo.ca.

Jake Rosenfeld: Department of Sociology, Washington University in St. Louis. E-mail: jrosenfeld@wustl.edu. 